Tạp chí Các Khoa học về Trái Đất, 38 (1), 66-78

$\begin{array}{r}\text { Viện Hàn lâm Khoa học và Công nghệ Việt Nam } \\ \text { Tạp chí Các Khoa học về Trái Đất } \\ \text { (VAST) } \\ \text { Website: http://www.vjs.ac.vn/index.php/jse } \\ \hline\end{array}$

\title{
Nghiên cứu đặc trưng quá trình lan truyền mặn nước dưới đất trong không gian 2 chiều theo mặt cắt
}

\author{
Nguyễn Văn Hoàng* ${ }^{1}$, Nguyễn Thành Công ${ }^{2}$, Phạm Lan Hoa ${ }^{1}$, Lê Thanh Tùng ${ }^{1}$ \\ ${ }^{I}$ Viện Địa chất, Viện Hàn lâm Khoa học và Công nghệ Việt Nam \\ ${ }^{2}$ Viện Thủy công, Viện Khoa học Thủy lợ Việt Nam
}

Chấp nhận đăng: 15 - 3 - 2016

\begin{abstract}
Study on the characteristics of salinity transport in 2D cross-section unconfined aquifer

Groundwater salinity is currently a problem of a great concern in coastal areas of Vietnam. The characteristics of the salinity transport in 2-dimensional cross section of aquifer under different boundary conditions, boundary values and groundwater flow velocity field have been determined through finite element modeling application. Two aquifer types have been considered: confined aquifer with constant velocity in space and unconfined aquifer with variable horizontal and vertical velocity in space. The influence of the boundary types and boundary values on the salinity transport had been concentrated and analyzed. The results of the salinity distribution configuration within the aquifer have significance in directional research of the actual problems. The similar salinity distribution of two cases: constant specified boundary and variable specified boundary the average of which is equal to the constant specified value had given opportunity to simplify complicated actual problems for utilization of simpler models.
\end{abstract}

Keywords: Groundwater, Salinity transport, Advection, Hydrodynamic Dispersion, Dirichlet, Neumann, Cauchy.

C2016 Vietnam Academy of Science and Technology

\section{Mở đầu}

Phương trình mô tả lan truyền mặn trong tầng chứa nước gồm 2 cơ chế là đối lưu (dịch chuyển theo vận tốc dòng thấm) và phân tán (muối trong nước tầng chứa nước bị phân tán) không xét đến tỷ trọng của nước trong không gian 2 chiều $(x, y)$ được mô tả theo phương trình đạo hàm riêng sau (Bear and Verruijt, 1987):

$$
D_{x} \frac{\partial^{2} C}{\partial x^{2}}+D_{y} \frac{\partial^{2} C}{\partial y^{2}}-v_{x} \frac{\partial C}{\partial x}-v_{y} \frac{\partial C}{\partial y}=R \frac{\partial C}{\partial t}
$$

trong đó: $D_{x}, D_{y}$ : các hệ số phân tán thủy động lực học theo hướng $x, y \quad\left(\mathrm{~L}^{2} / \mathrm{T}\right)$ (thông thường được

*Tác giả liên hệ, Email: N_V_Hoang_VDC@yahoo.com lấy bằng tích của vận tốc Đăc-xi và độ phân tán (Bear and Verruijt, 1987), $C$ : nồng độ vật chất trong nước $\left(\mathrm{M} / \mathrm{L}^{3}\right), v_{x}, v_{y}$ : vận tốc thực của dòng nước theo hướng $x$ và $y(\mathrm{M} / \mathrm{T}), R$ : hệ số chậm trễ; $t$ : thời gian $(\mathrm{T})$;

Bất kỳ quá trình lan truyền mặn trong một tầng chứa nước nào đó đều có điều kiện ban đầu và điều kiện biên nhất định để phương trình (1) nêu trên có một lời giải duy nhất. Điều kiện ban đầu là phân bố nồng độ muối ăn trong nước vào thời điểm ban đầu tùy ý $t=t_{0}$ tại mọi vị trí trong tầng chứa nước $C=C_{o}(x, y)$. Điều kiện biên sẽ trình bày trong mục 2 dưới đây.

Trong mô hình mô phỏng lan truyền mặn trong nước dưới đất, các quá trình trao đổi hấp phụ với môi trường tầng chứa nước được thể hiện bởi các 


\section{N.V. Hoàng và nnk/Tạp chí Các Khoa học về Trái Đất, Tập 38 (2016)}

công thức giải tích nhất định với các thông số mà qua đó sẽ cho kết quả là có sự hấp phụ muối tù̀ nước của đất tầng chứa nước, hay sự giải phóng muối từ đất tầng chứa nước ra nước dưới đất hay không có sự hấp phụ hoặc sự giải phóng này. Quá trình hấp phụ hoặc giải phóng được thể hiện qua một thông số gọi là hệ số chậm chễ $R: R$ lớn hơn 1 là muối bị đất tầng chứa nước hấp phụ, $R$ bé hơn 1 là xảy ra quá trình giải phóng muối từ môi trường đất ra môi trường nước, $R$ bằng 1 không xảy ra quá trình hấp phụ hoặc giải phóng muối của đất tầng chứa nước. Trong nghiên cứu này cho rằng $R=1$ vì tầng chứa nước không chứa các vật chất hấp phụ muối trong nước.

Tuy nhiên với cùng các cơ chế lan truyền mặn, các kiểu điều kiện biên khác nhau, sự thay đổi giá trị liên quan đến nồng độ muối trên biên, đặc điểm trường vận tốc dòng chảy nước dưới đất,... sẽ dẫn đến đặc trưng lan truyền mặn, và từ đó là phân bố nồng độ muối ăn trong nước dưới đất trong tầng chứa nước, khác nhau theo không gian và thời gian. Trong công trình này, các đặc trưng kết quả lan truyền mặn ở các điều kiện khác nhau này được trình bày nhằm cung cấp bức tranh qui luật và xu hướng diễn biến và phân bố nồng độ mặn trong nước tầng chứa nước trong không gian theo mặt cắt. Phương pháp được sử dụng trong mô hình mô phỏng lan truyền mặn là phương pháp phần tử hữu hạn sử dụng phần tử tuyến tính (Zienkiewicz and Morgan, 1983) với sơ đồ phần tử thời gian trung tâm có hệ số bằng 0,5 (tức là sơ đồ sai phân trung tâm theo thời gian) (Huyakorn and Pinder, 1987).

\section{Các kiểu điều kiện biên mô hình lan truyền mặn nước dưới đất}

Như được biết rộng rãi trong toán học ứng dụng liên quan đến phương trình vi phân, có ba kiểu điều kiện biên đối với các bài toán vi phân là (Bear and Verruijt, 1987): (i) biên Dirichlet; (ii) biên Neumann; (iii) biên Cauchy được đặt theo tên của các nhà toán học lần đầu đưa ra các điều kiện biên trong các phương trình vi phân. Vì vậy trong các bài toán lan truyền mặn và các chất ô nhiễm trong nước dưới đất, các điều kiện biên cụ thể cũng cần phải được xác định để có lời giải đúng đắn nhất, phản ánh đúng thực chất quá trình lan truyền. Như vậy, các bài toán lan truyền mặn và chất ô nhiễm gồm các điều kiện biên khác nhau là: (i) biên Dirichlet (nồng độ muối hoặc chất ô nhiễm đã xác định trên biên); (ii) biên Neumann (đạo hàm nồng độ muối hoặc chất ô nhiễm trên biên đã biết); (iii) biên Cauchy (đồng thời nồng độ và đạo hàm nồng độ muối hoặc chất ô nhiễm trên biên đã biết). Một miền mô hình lan truyền mặn có thể có các đoạn biên có kiểu điều kiện biên cụ thể khác nhau, kiểu điều kiện biên và giá trị biên có thể không thay đổi hoặc thay đổi. Các kiểu điều kiện biên cụ thể như sau:

+ Biên kiểu Dirichlet: nồng độ muối hoặc chất ô nhiễm đã xác định trên biên:

$$
C=C_{c} \operatorname{trên} \Gamma_{c}
$$

Có thể xảy ra các trường hợp sau:

- Nồng độ trên biên chỉ tồn tại trong một thời gian rất ngắn (thậm chí được xem như một thời điểm tức thời), ngoài thời gian đó, nồng độ muối trên biên bằng nồng độ muối trong nước dưới đất ở điều kiện tự nhiên;

- Nồng độ trên biên không đổi theo thời gian;

- Nồng độ trên biên xác định nhưng thay đổi theo thời gian;

+ Biên kiểu Neumann: Biên có gradient nồng độ pháp tuyến với đường biên xác định:

$$
\frac{\partial C}{\partial \mathbf{n}}=q \text { trên } \Gamma_{q_{c}}
$$

- Gradient nồng độ trên biên không đổi theo thời gian;

- Gradient nồng độ trên biên xác định nhưng thay đổi theo thời gian;

+ Biên Cauchy: Biên có dòng vật chất khuếch tán-đối lưu pháp tuyến với biên đã biết:

$$
v_{\mathbf{n}} C-D_{\mathbf{n}} \frac{\partial C}{\partial \mathbf{n}}=\frac{v_{0} C_{v}}{n} \text { trên } \Gamma_{q_{v c}}
$$

ở đây: $v_{0}, C_{v}$ tương ứng là dòng chất lỏng và nồng độ vật chất của chất lỏng này qua biên.

Cùng một tầng chứa nước có hình dáng nhất định với các thông số thủy lực và lan truyền mặn nhất định, nhưng có các kiểu điều kiện biên khác nhau sẽ cho kết quả lan truyền mặn khác nhau theo không gian và thời gian. 


\section{Tạp chí Các Khoa học về Trái Đất, 38 (1), 66-78}

Trong khuôn khổ thực hiện Đề tài Nghiên cứu cơ bản định hướng ứng dụng "Nghiên cứu xây dựng phần mềm mô hình phần tử hữu hạn mô phỏng chuyển động và lan truyền các chất ô nhiễm và nhiễm mặn trong môi trường nước dưới đất-ứng dụng cho khu vực ven biển miền Trung" có mã số ĐT.NCCB-ĐHU'D.2012-G/04, phần mềm mô hình lan truyền vật chất (trong đó có lan truyền mặn) một chiều (Phạm Lan Hoa, 2015), hai chiều theo diện (Lê Thanh Tùng, 2015) và hai chiều theo mặt cắt (Nguyễn Văn Hoàng, 2015) đã được xây dựng và kiểm tra-kiểm chứng độ chính xác của chương trình cũng như độ chính xác của các kết quả của mô hình theo các kết quả của lời giải giải tích chính xác (Phạm Lan Hoa, 2015; Lê Thanh Tùng, 2015; Nguyễn Văn Hoàng, 2015).

\section{Mô hình có điều kiện biên Ririchlet}

Kiểu điều kiện biên Dirichlet là biên mà nồng độ muối trên biên đã được xác định. Cho rằng có tầng chứa nước nằm giữa hai sông $\mathrm{A}$ và $\mathrm{B}$ song song với nhau mà dòng chảy có hướng từ sông $\mathrm{A}$ vào tầng chứa nước rồi ra sông $\mathrm{B}$ như thể hiện trên hình 1. Lưu lượng nước trên hai sông đủ lớn so với lưu lượng nước dưới đất chảy qua tầng chứa nước thoát vào sông $\mathrm{B}$, đồng thời đủ lớn để đẩy toàn bộ nước biển tràn vào sông $\mathrm{A}$ trong 1 ngày đêm. Vì vậy, có thể xem rằng tại biên với sông $\mathrm{B}$ nước dưới đất có nồng độ muối bằng nồng độ muối của chính nước sông $\mathrm{B}$. Còn tại biên với sông $\mathrm{A}$, nồng độ muối trong nước dưới đất bằng nồng độ muối của nước sông $\mathrm{A}$ là $27 \mathrm{~g} / 1$ trong một khoảng thời nhất định (trong bài viết lấy bằng 1 ngày và bằng bước thời gian mô hình), xảy ra do nước biển tràn vào sông $\mathrm{A}$ và sau 1 ngày nước trong sông $\mathrm{A}$ mới vào có lại nồng độ muối là $0,1 \mathrm{~g} / 1$.

Hai trường hợp mô hình được đánh giá so sánh là tầng chứa nước có áp (có trường vận tốc không thay đổi theo không gian) và tầng chứa nước không có áp (có trường vận tốc thay đổi theo không gian).

Miền mô hình đối với cả hai trường hợp tầng chứa nước có áp lực và tầng chứa nước không có áp lực được chia ra các phần tử kích thước $1 \mathrm{~m}$ theo chiều ngang và chiều đứng. Bước thời gian là 1 ngày, tổng thời gian là 370 ngày.

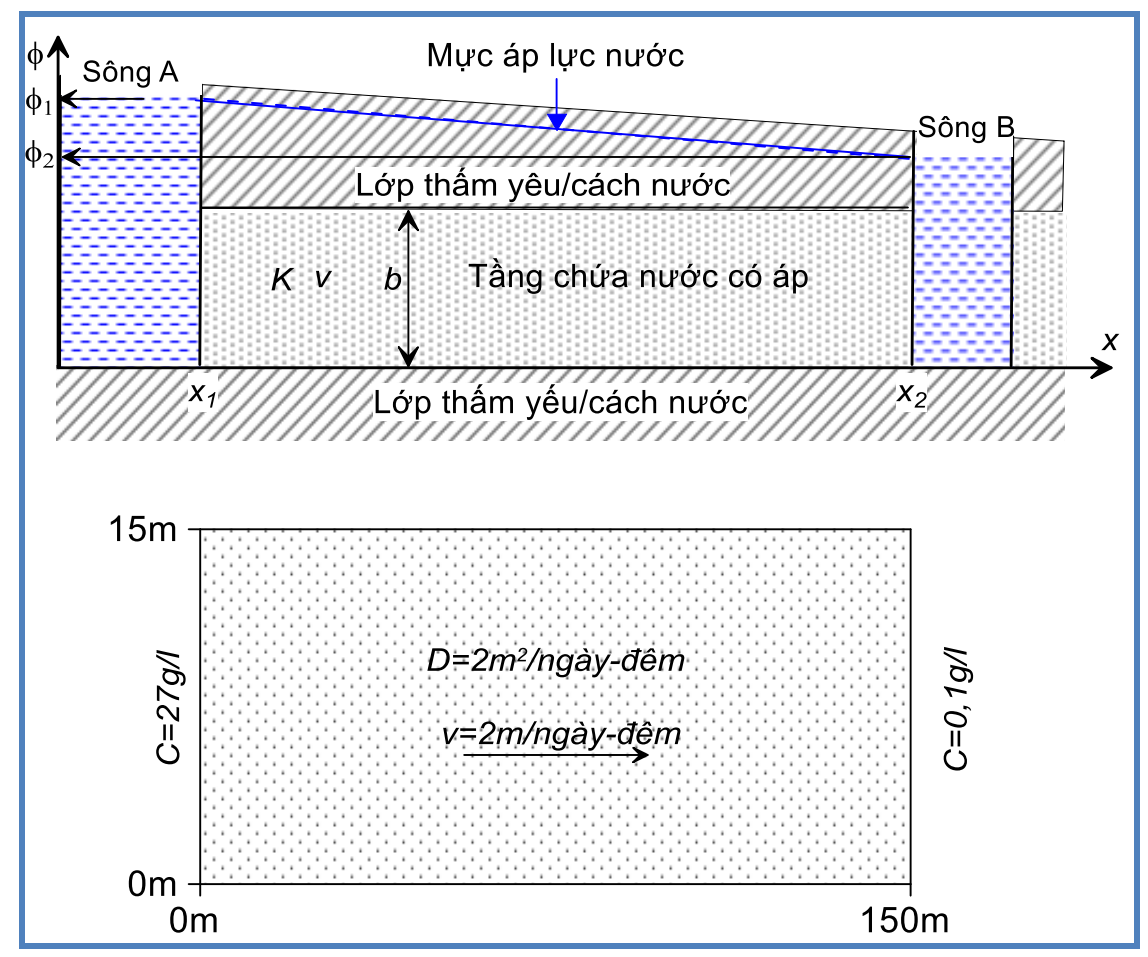

Hình 1. Sơ đồ mặt cắt và miền mô hình $2 \mathrm{D}$ theo mặt cắt tầng chứa nước có áp lực 
N.V. Hoàng và nnk/Tạp chí Các Khoa học về Trái Đất, Tập 38 (2016)

Với các thông số về mực nước và hệ số thấm của tầng chứa nước sẽ xác định được vận tốc thấm Đắc-xi. Đối với tầng chứa nước có áp cho rằng vận tốc là $v=2 \mathrm{~m} /$ ngày-đêm, độ phân tán dọc $a_{l}=1 \mathrm{~m}$, nên hệ số phân tán thủy động lực là $D=2 \mathrm{~m}^{2} /$ ngàyđêm. Lấy khoảng cách giữa bờ biển và sông là $150 \mathrm{~m}$. Như vậy sơ đồ mô hình nguyên lý lan truyền mặn một chiều trong trường hợp này có thể được thể hiện trên hình 1 .

Đối với tầng chứa nước không có áp, cho rằng trường vận tốc như sau (có giá trị trung bình trên toàn miền $\approx 2 \mathrm{~m} /$ ngày-đêm):

- Tại vị trí $x_{1}$ ở mép phía sông $\mathrm{A}$ vận tốc dòng nước dưới đất theo phương ngang là $v=2 \mathrm{~m} /$ ngày- đêm, và giảm dần theo độ sâu một cách tuyến tính mà ở đáy là $v=1 \mathrm{~m} /$ ngày-đêm;

- Theo phương ngang, vận tốc tăng dần do tầng chứa nước là tầng không có áp lực, khi mà mực nước dưới đất là hàm parabol, chiều dày giảm thì vận tốc phải tăng lên để đảm bảo lưu lượng không thay đổi. Trong bài viết sử dụng vận tốc theo phương ngang tỷ lệ tuyến tính theo khoảng cách;

- Vận tốc theo phương thẳng đứng lấy bằng 0,1 vận tốc theo phương ngang;

Như vậy, sơ đồ mô hình nguyên lý lan truyền mặn hai chiều theo mặt cắt trong trường hợp này có thể được thể hiện trong mặt cắt dưới trên hình 2.

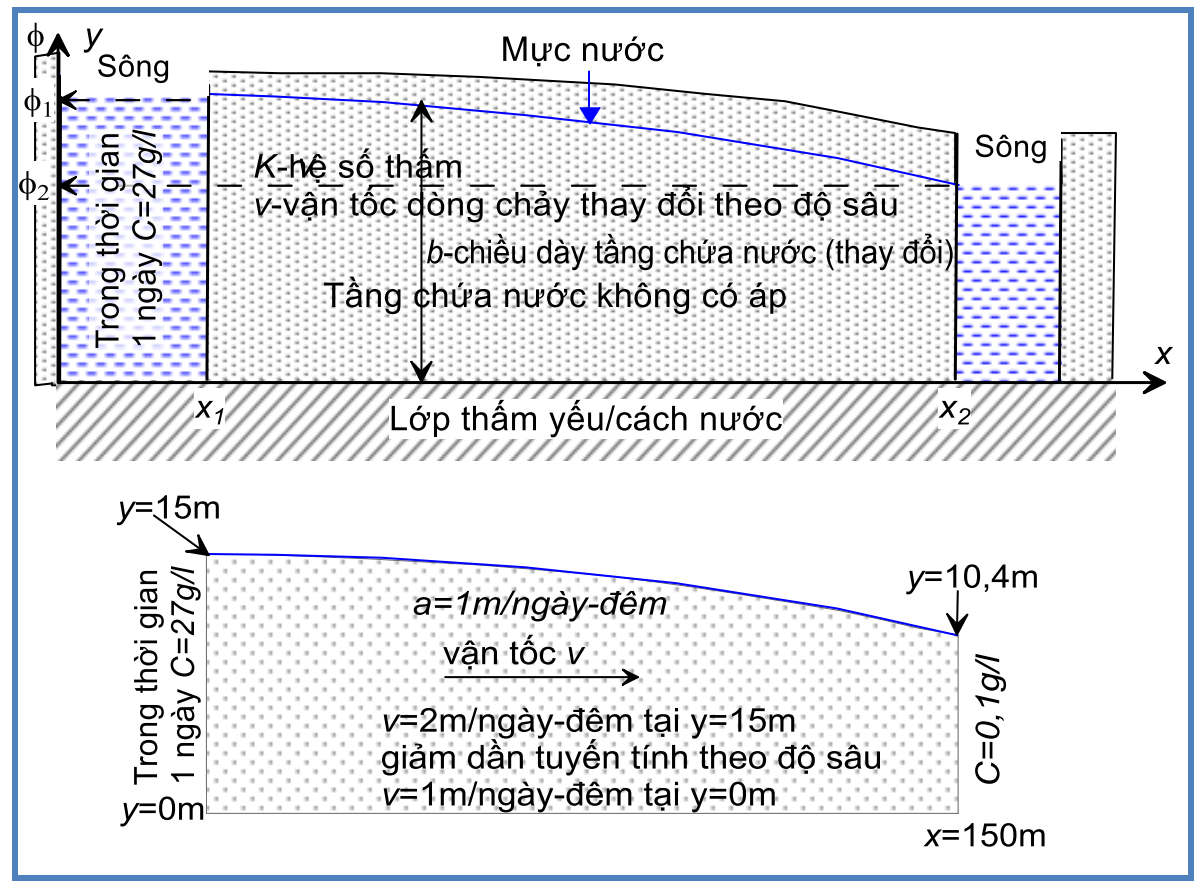

Hình 2. Sơ đồ mặt cắt và miền mô hình $2 \mathrm{D}$ theo mặt cắt tầng chứa nước không có áp lực

Lưới phần tử hữu hạn đối với tầng chứa nước có áp thể hiện trên hình 3 và đối với tầng chứa nước không có áp thể hiện trên hình 4 . Vận tốc dòng chảy theo phương $x$ và $y$ của tầng chứa nước không áp tương ứng thể hiện trên hình 5 và 6 (lưu ý: vận tốc theo phương thẳng đứng có hướng từ trên xuống, trong khi trục $y$ hướng từ dưới lên nên trong chương trình tính toán vận tốc theo hướng $y$ có giá trị âm).

Trong trường hợp này, miền mô hình, đặc biệt là theo chiều sâu tầng chứa nước, không còn vuông vắn hình chữ nhật hoặc hình vuông như trên hình 1 nữa. 
Tạp chí Các Khoa học về Trái Đất, 38 (1), 66-78

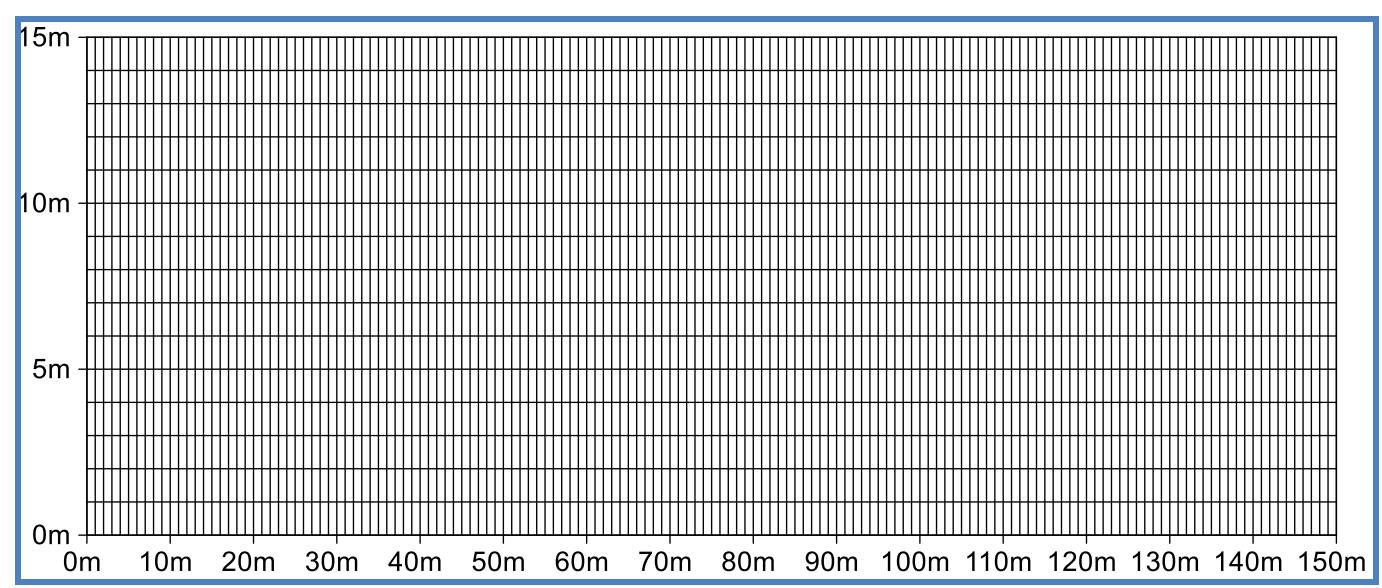

Hình 3. Lưới phần tử hữu hạn tầng chứa nước có áp lực

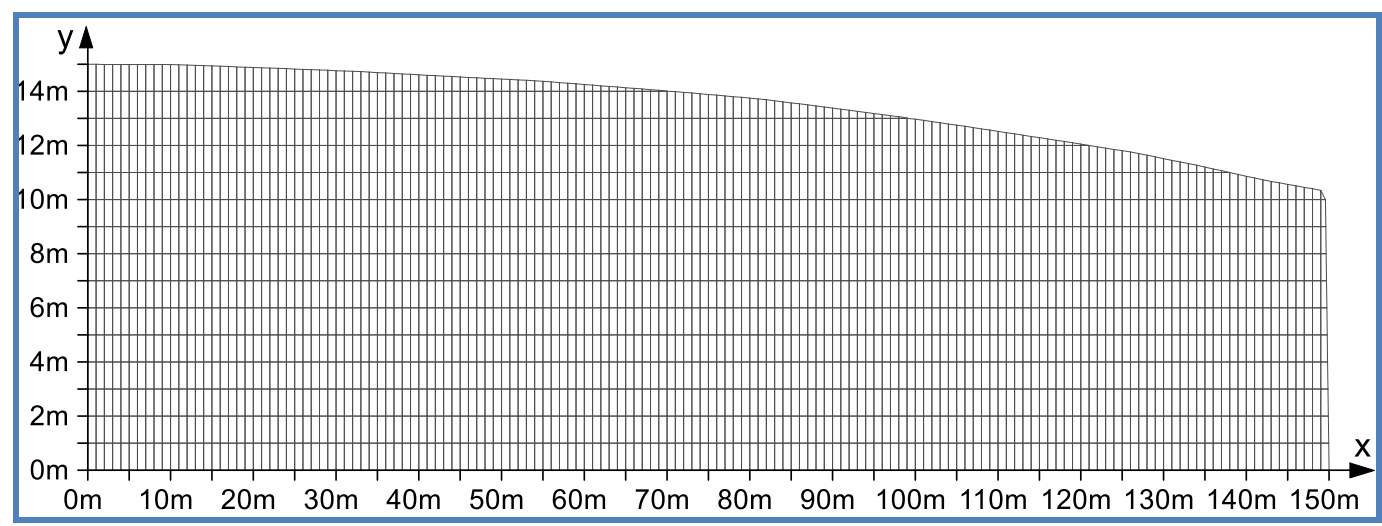

Hình 4. Lưới phần tử hữu hạn tầng chứa nước không có áp lực

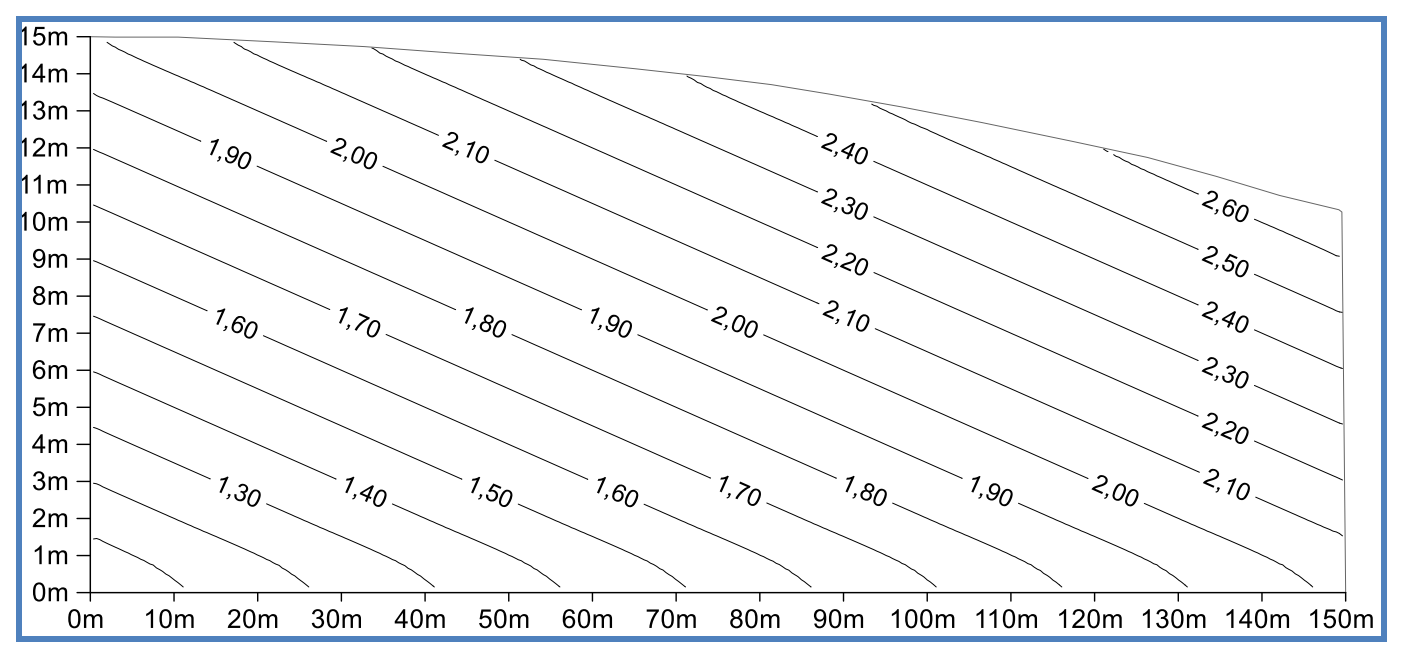

Hình 5. Vận tốc theo phương ngang trong tầng không có áp (m/ngày-đêm) 
N.V. Hoàng và nnk/Tạp chí Các Khoa học về Trái Đất, Tập 38 (2016)

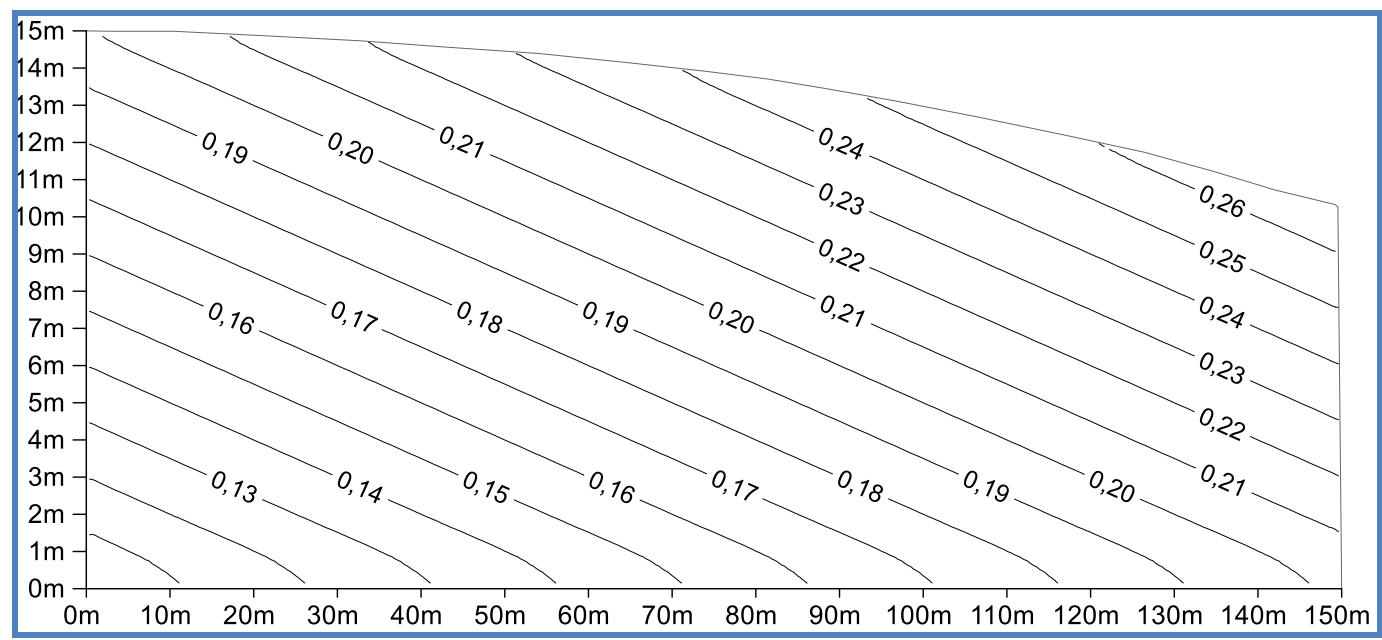

Hình 6. Vận tốc theo phương đứng trong tầng không có áp (m/ngày-đêm)

3.1. Nồng độ trên biên chỉ tồn tại trong một thời gian rất ngắn

Trong trường hợp này, nồng độ muối của nước sông $\mathrm{A}$ là $27 \mathrm{~g} / \mathrm{l}$ trong một thời gian là 1 ngày (có thể xảy ra do nước biển tràn vào, chẳng hạn sóng thần), sau 1 ngày đêm đó nước trong sông $\mathrm{A}$ có nồng độ muối là $0,1 \mathrm{~g} / 1$. Mô hình lan truyền mặn đối với hai tầng chứa nước có áp và không có áp đã được thực hiện cho khoảng thời gian là 165 ngày. Trên hình 7 thể hiện phân bố nồng độ vào thời gian sau 1 tháng, và hình 8 là thời gian sau 2 tháng. Trong tầng chứa nước luôn có một dải có nồng độ muối cao nhất, và nồng độ giảm dần về hai phía. Kết quả cho thấy phân bố nồng độ muối theo chiều sâu và chiều ngang trong tầng chứa nước không có áp đã bị phân dị hoàn toàn so với trường hợp tầng chứa nước có áp là không thay đổi theo chiều sâu, mà mức độ phân dị (các đường đẳng nồng độ có hướng dốc thoải hơn) gia tăng đáng kể theo thời gian.

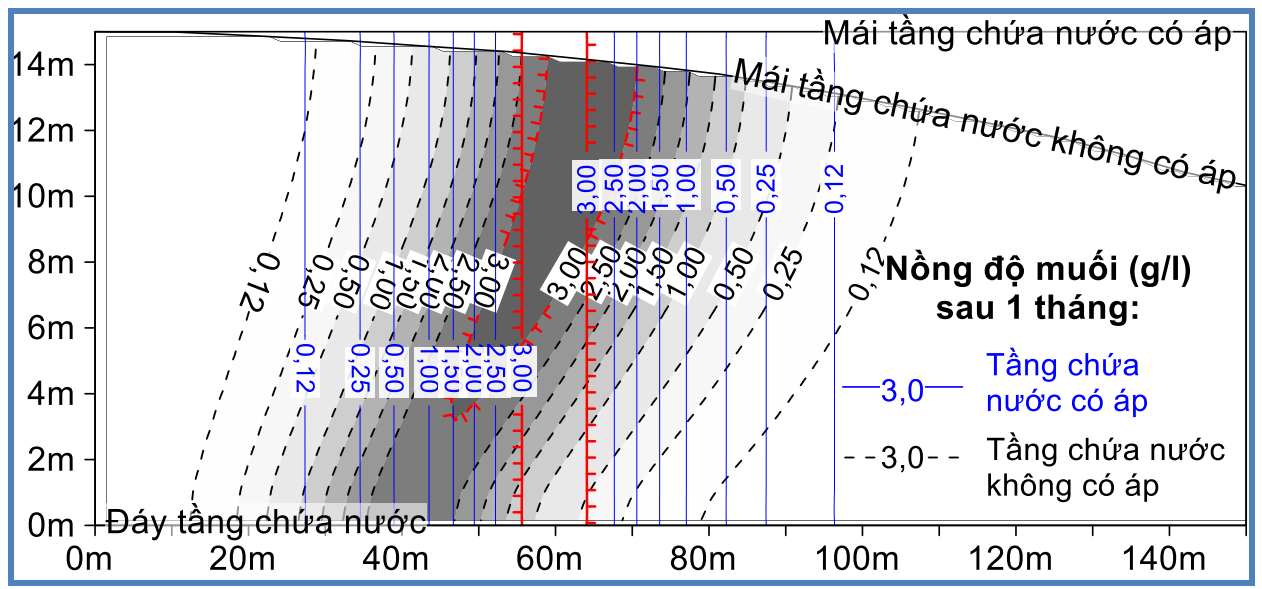

Hình 7. Phân bố nồng độ muối vào thời điểm sau 1 tháng 
Tạp chí Các Khoa học về Trái Đất, 38 (1), 66-78

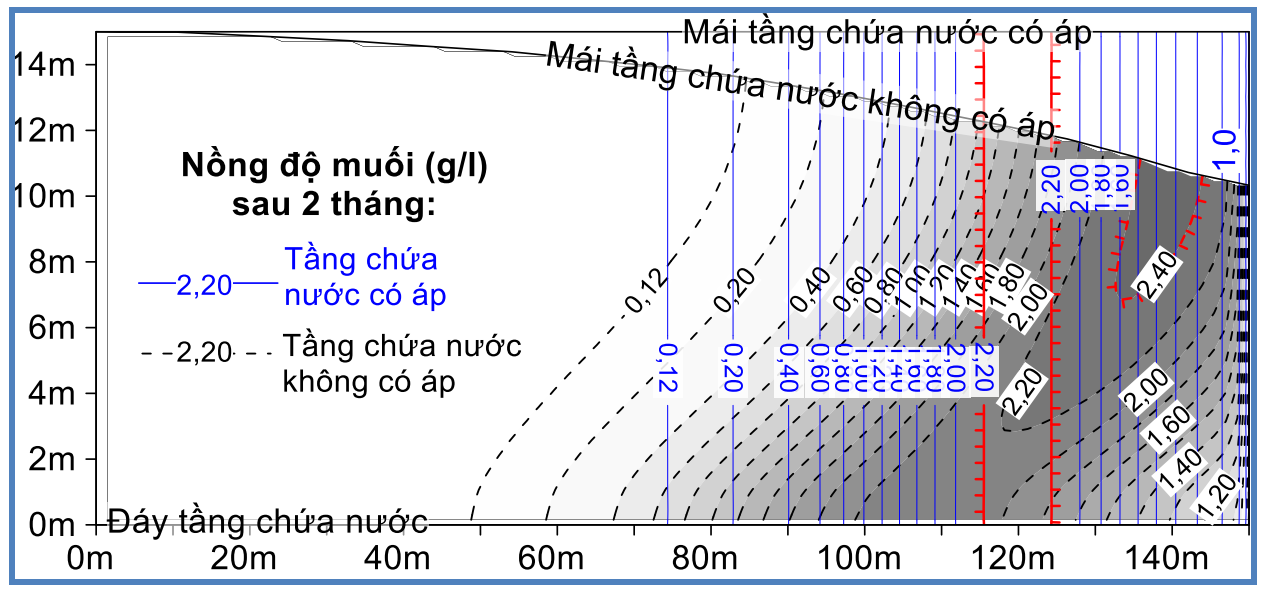

Hình 8. Phân bố nồng độ muối vào thời điểm sau 2 tháng

\subsection{Nồng độ trên biên là hằng số trong mọi thời điểm}

Trường hợp này tương tự như trường hợp trên trong mục 3.1, như nồng độ mối trong sông $\mathrm{A}$ không thay đồi. Chẳng hạn sông $\mathrm{A}$ là một đoạn sông chết lưu thông với biển mà nồng độ muối trong nước luôn là $27 \mathrm{~g} / \mathrm{l}$. Kết quả được thể hiện đối với hai tầng chứa nước vào hai thời điểm sau 1 tháng và 2 tháng trên hình 9 và 10 . Các đường cong đẳng nồng độ muối cũng có hình dáng tương tự như trường hợp 3.1, nhưng ở đây thay vì dải có nồng độ cao nhất ở phía giữa tầng theo phương ngang là dải nồng độ cao nhất nằm hoàn toàn về phía tiếp giáp với biên có nồng độ muối không thay đổi.

\subsection{Nồng độ trên biên là hằng số chỉ trên 1 đoạn biên theo phương thẳng đúng}

Trường hợp này tương tự trường hợp ở mục 3.2 , nhưng khác nhau ở chỗ đáy sông bên trái nằm ở giữa chiều dày tầng chứa nước, đáy có lớp bùn, nước không thấm qua do lớp bùn thấm yếu và mực nước của tầng chứa nước bằng mực nước sông. Nồng độ muối trong nước sông bên trái này là $27 \mathrm{~g} / \mathrm{l}$; nước dưới đất chảy từ phía bên trái dưới lớp bùn có nồng độ muối là $0,1 \mathrm{~g} / \mathrm{l}$. Như vậy sơ đồ mô hình nguyên lý lan truyền mặn hai chiều trong trường hợp này có thể được thể hiện trên hình 11 . Kết quả mô hình phần tử hữu hạn lan truyền mặn được thể hiện cho các thời điểm 10 ngày, 20 ngày, 1 tháng, 2 tháng và 3 tháng tương ứng trên các hình 12-15.

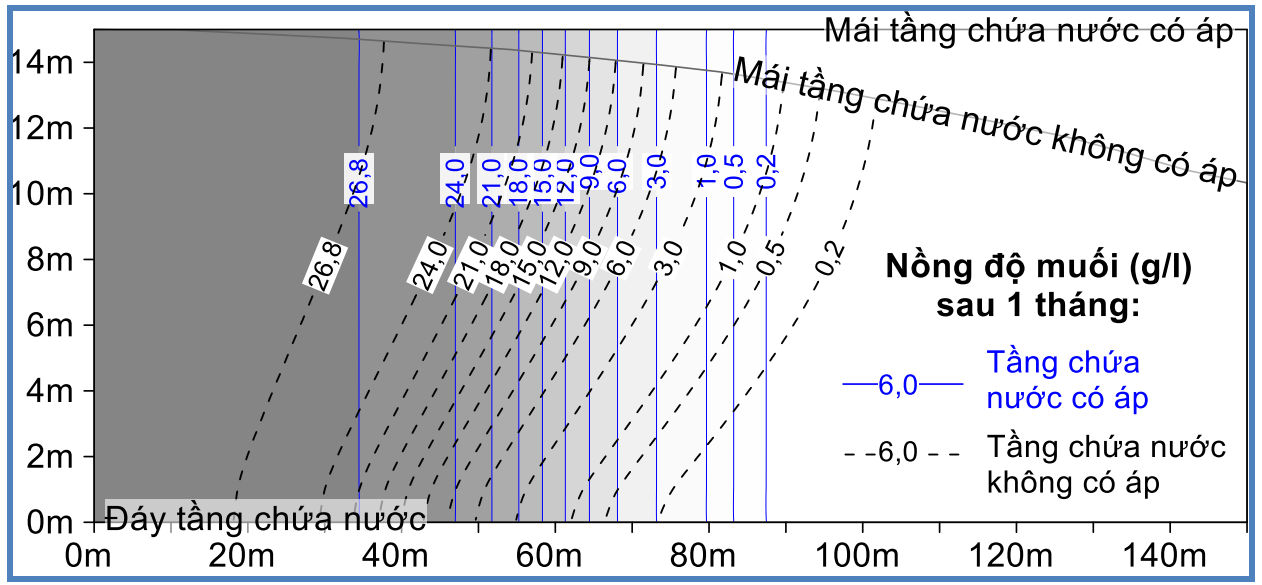

Hình 9. Phân bố nồng độ muối theo không gian vào thời điểm sau 1 tháng 
N.V. Hoàng và nnk/Tạp chí Các Khoa học về Trái Đất, Tập 38 (2016)

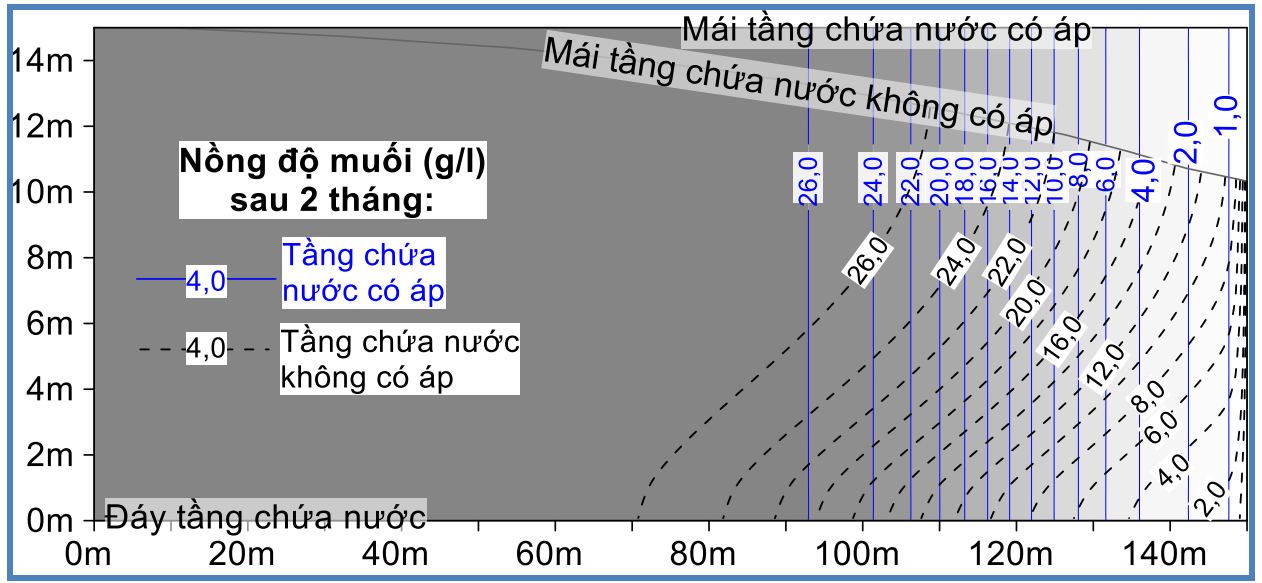

Hình 10. Phân bố nồng độ muối theo không gian vào thời điểm sau 2 tháng

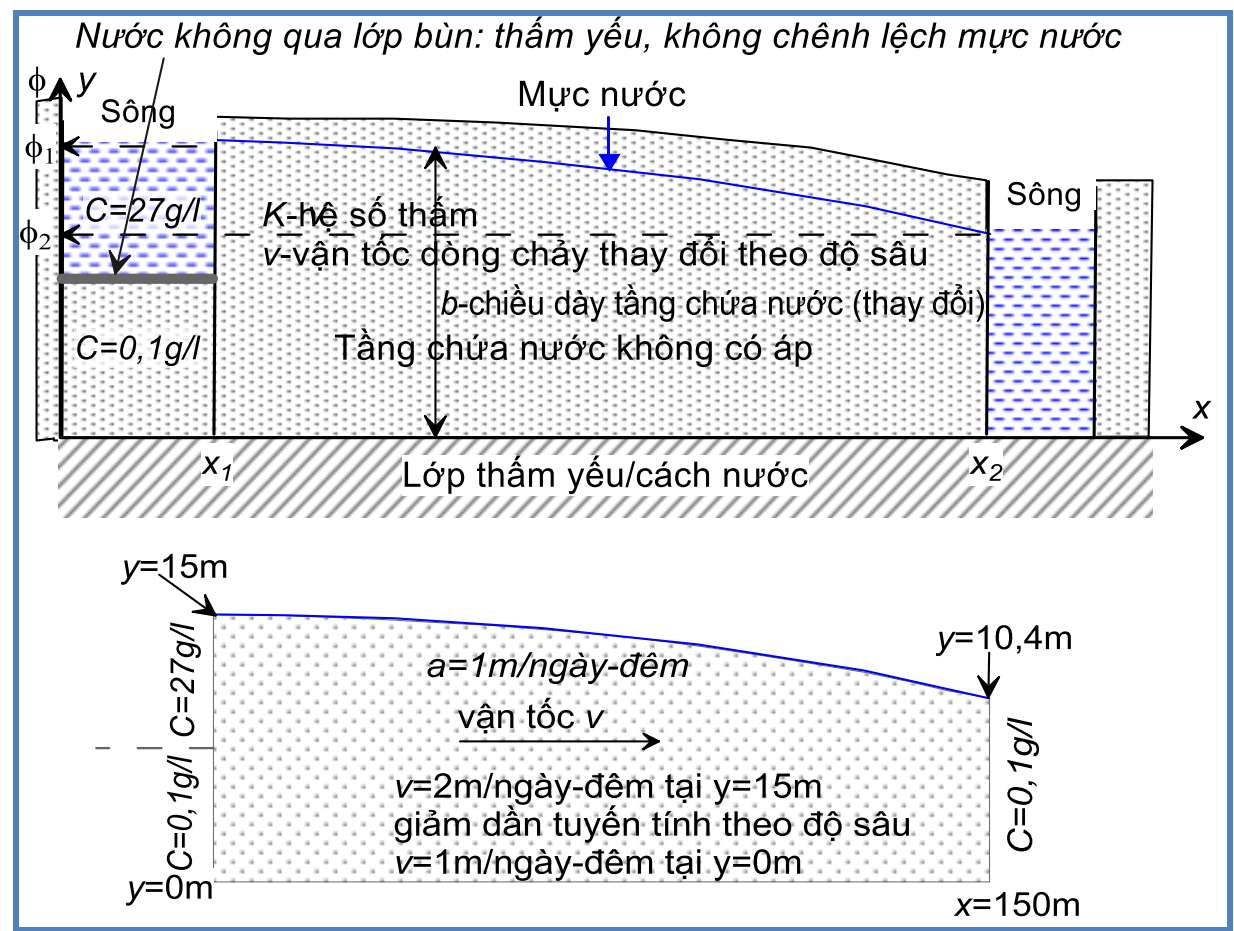

Hình 11. Điều kiện biên phân hóa theo chiều sâu

Kết quả cho thấy mặc dù một dưới tầng chứa nước luôn luôn được dòng nước dưới đất có nồng độ muối rất thấp là $0,1 \mathrm{~g} / 1$ từ phía sông $\mathrm{A}$ chảy vào, nhưng lưỡi mặn phát triển rất nhanh vào nửa dưới của tầng do cơ chế đối lưu và phân tán vì trường vận tốc lớn ở phía trên và tăng dần sang bên phải. Chỉ một diện tích nửa hình nón rất nhỏ nằm dưới đáy sông kéo sang phải ở khoảng cách khoảng $25 \mathrm{~m}$ là có nồng độ muối dưới $1 \mathrm{~g} / \mathrm{l}$. 
Tạp chí Các Khoa học về Trái Đất, 38 (1), 66-78

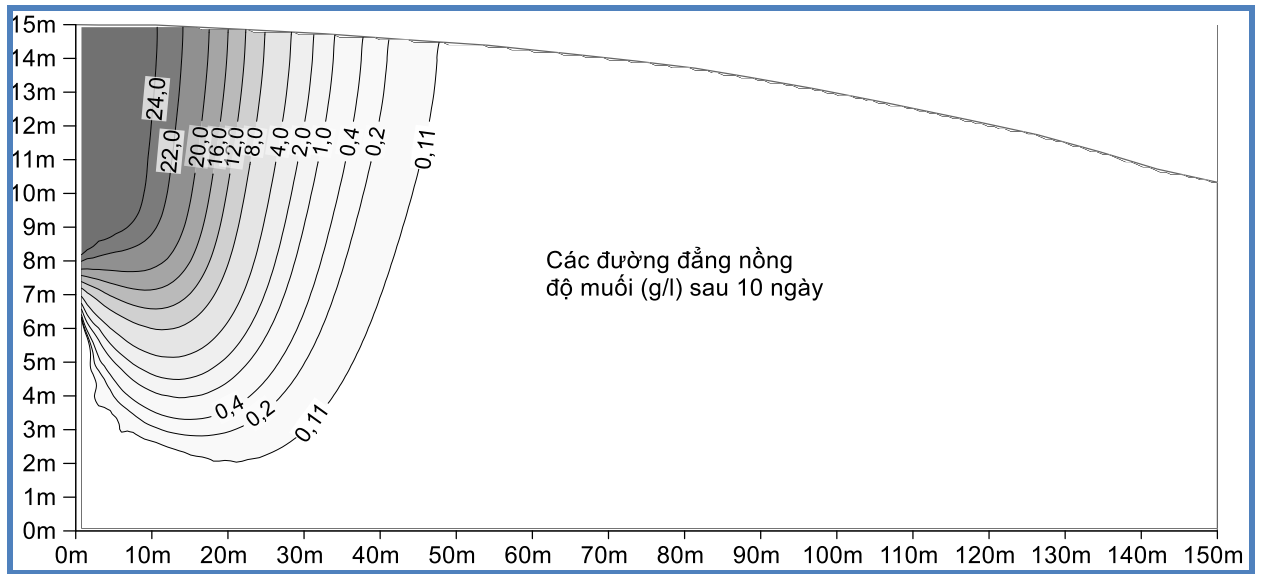

Hình 12. Phân bố nồng độ muối theo không gian vào thời điểm sau 10 ngày

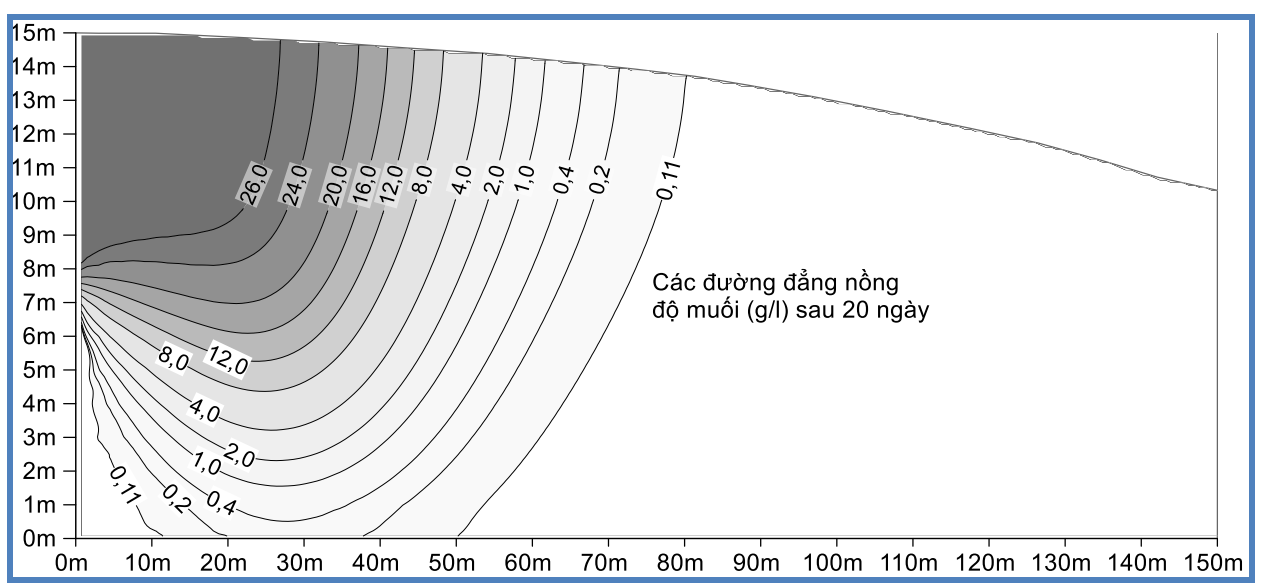

Hình 13. Phân bố nồng độ muối theo không gian vào thời điểm sau 20 ngày

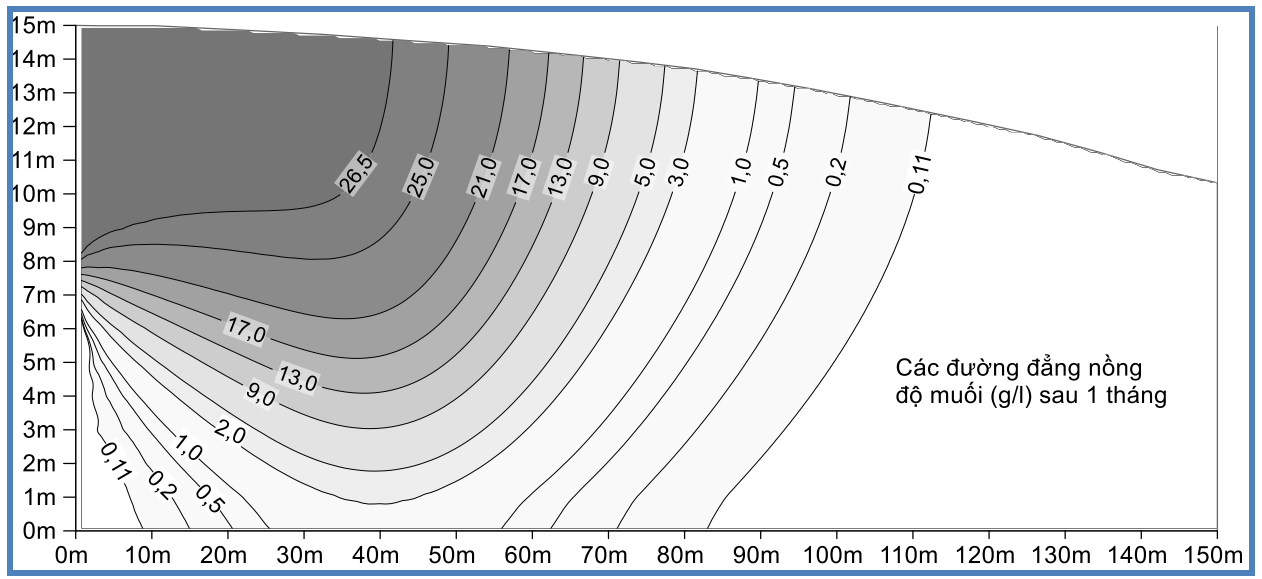

Hình 14. Phân bố nồng độ muối theo không gian vào thời điểm sau 1 tháng 
N.V. Hoàng và nnk/Tạp chí Các Khoa học về Trái Đất, Tập 38 (2016)

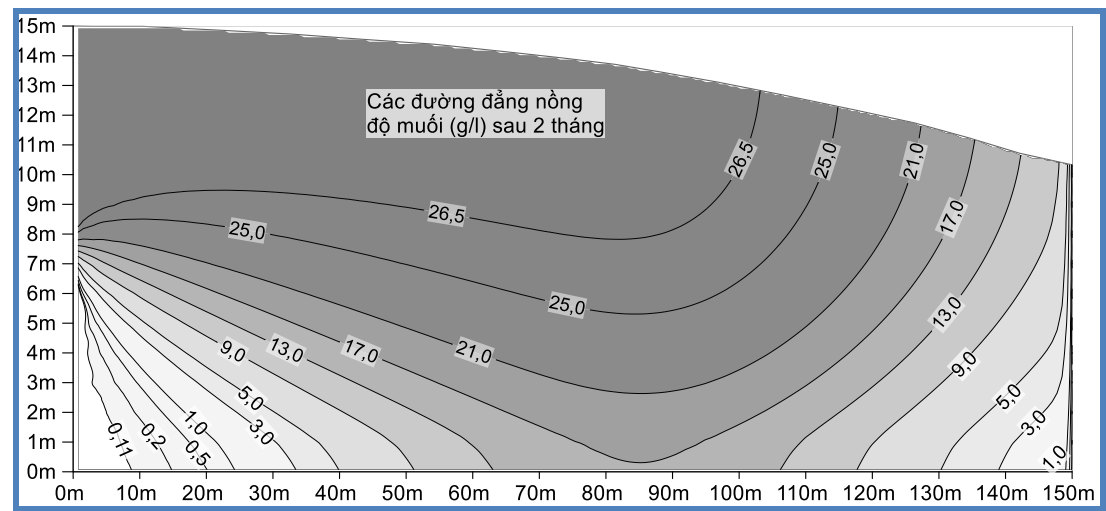

Hình 15. Phân bố nồng độ muối theo không gian vào thời điểm sau 2 tháng

\subsection{Nồng độ trên biên là một hàm số theo thời gian}

Tương tự trường hợp trong mục 3.3 nêu trên, nhưng nồng độ trong sông $\mathrm{A}$ thay đổi theo thời gian một cách có chu kỳ, chẳng hạn là cửa sông bị ảnh hưởng triều nồng độ muối thay đổi theo thời gian theo dạng đồ thị hình sin. Nồng độ muối cực đại là $27 \mathrm{~g} / \mathrm{l}$, cực tiểu là $0,1 \mathrm{~g} / \mathrm{l}$ và trung bình là $13,5 \mathrm{~g} / \mathrm{l}$ và thể hiện trên hình 16 minh họa cho 4 ngày.

Để mô phỏng điều kiện biên theo được chu kỳ biến đổi theo ngày dạng hình sin, bước thời gian được chọn là $1 / 16$ ngày. Thời gian mô hình là 365 ngày, tức là 5840 bước thời gian mô hình. Phân tích kêt quả cho thấy phân bố nổng độ muối trong tầng chứa nước theo không gian và thời gian rất tương tự kêt quả trường hợp nồng độ muối trên biên không đổi là 13,5g/l. Sự khác biệt không đáng kể chi thể hiện ở dải nồng độ cao (gần về phía biên) và dải nồng độ rất thấp (ở phía biên đối diện). Điều này được thể hiện trên hình 17 so sánh giữa trường hợp này với trường hợp biên có nồng độ muối không đồi là $13,5 \mathrm{~g} / \mathrm{l}$ vào thời điểm sau 20 ngày.

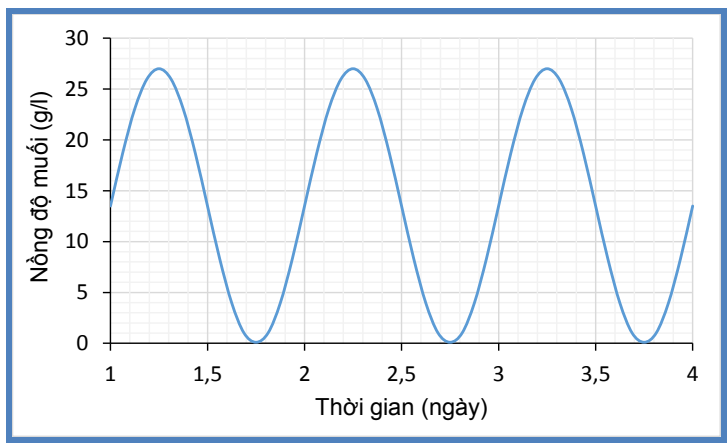

Hình 16. Nồng độ muối trên biên biến đổi chu kỳ theo ngày

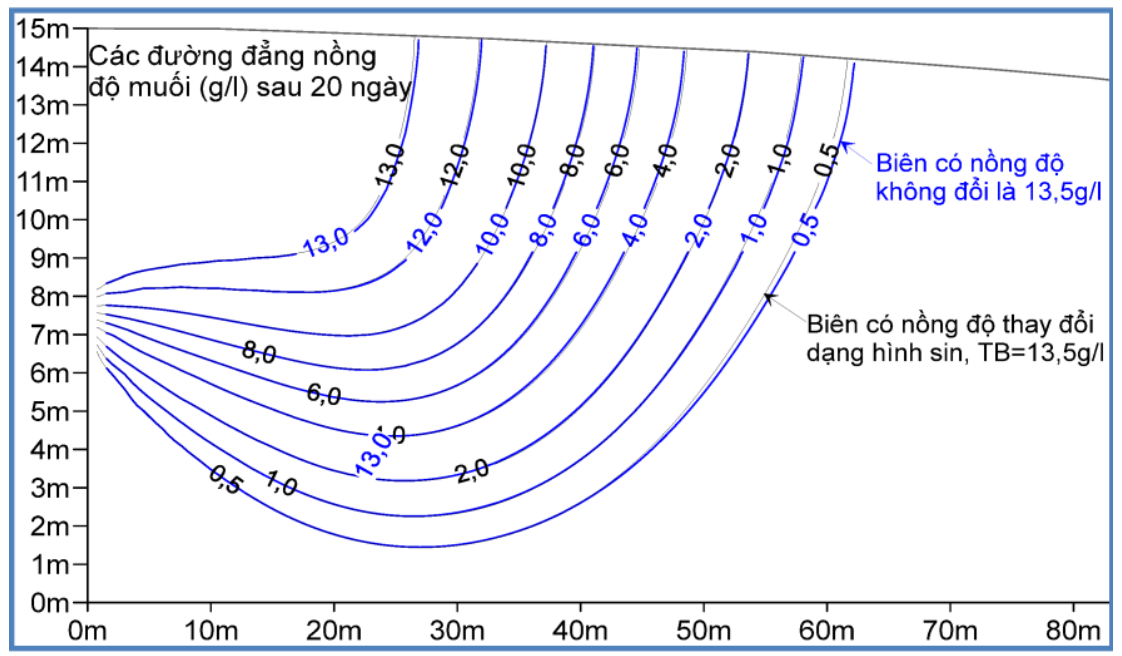

Hình 17. Phân bố nồng độ muối theo không gian và thời gian: sau 20 ngày 
Tạp chí Các Khoa học về Trái Đất, 38 (1), 66-78

\section{Mô hình trường hộp điều kiện biên Cauchy}

Điều kiện biên Cauchy là điều kiện mà lưu lượng muối qua biên đã được xác định. Một điều luôn luôn cần lưu ý khi giải bài toán này là lưu lượng dòng chảy nước dưới đất qua biên bằng đúng lưu lượng dòng chảy trong tầng chứa nước. Trong trường hợp lưu lượng qua biên lớn hơn hoặc nhỏ hơn lưu lượng chảy trong tầng chứa nước thì cần tiến hành tính toán xác định lưu lượng dòng muối "quy đổi" làm giá trị biên. Thí dụ, nếu lưu lượng dòng chảy vào từ biên lớn hơn dòng chảy trong tầng chứa nước trước khi nước từ biên chảy vào thì trước tiên phải tính nồng độ muối trong các phần tử dọc biên theo công thức pha trộn 2 thể tích nước có nồng độ khác nhau, sau đó tính tích của giá trị chênh lệch lưu lượng dòng từ biên vào và lưu lượng nước trong tầng chứa nước trước khi nước từ biên chảy vào nhân với chênh lệch nồng độ nước dưới đất trước khi pha trộn và sau khi pha trộn sẽ là giá trị biên "quy đổi". Kết quả mô hình thể hiện trên các hình từ 18 đến 22 đối với các thời điểm 10 ngày, 20 ngày, 1 tháng, 2 tháng và 3 tháng. Hình dáng phân bố nồng độ muối trong nước dưới đất trong trường hợp này tương tự như trường hợp 3.3 nêu trên khi một phần biên có điều kiện biên Dirichlet. Đây là một gợi ý cho công tác xác định sự tương tự giữa hai trường hợp này, nhằm có cơ sở nội suy kết quả trường hợp biên Cauchy từ kết quả của trường hợp biên Neumann để chuyển từ bài toán rất phức tạp sang bài toán đơn giản hơn nhiều.

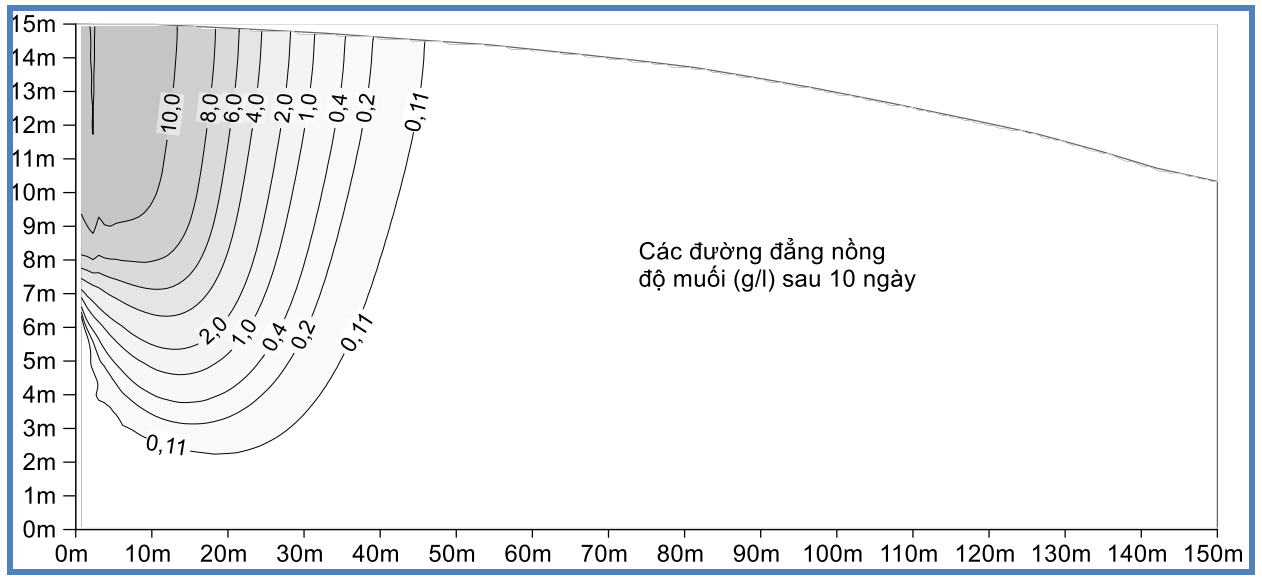

Hình 18. Phân bố nồng độ muối theo không gian và thời gian: sau 10 ngày

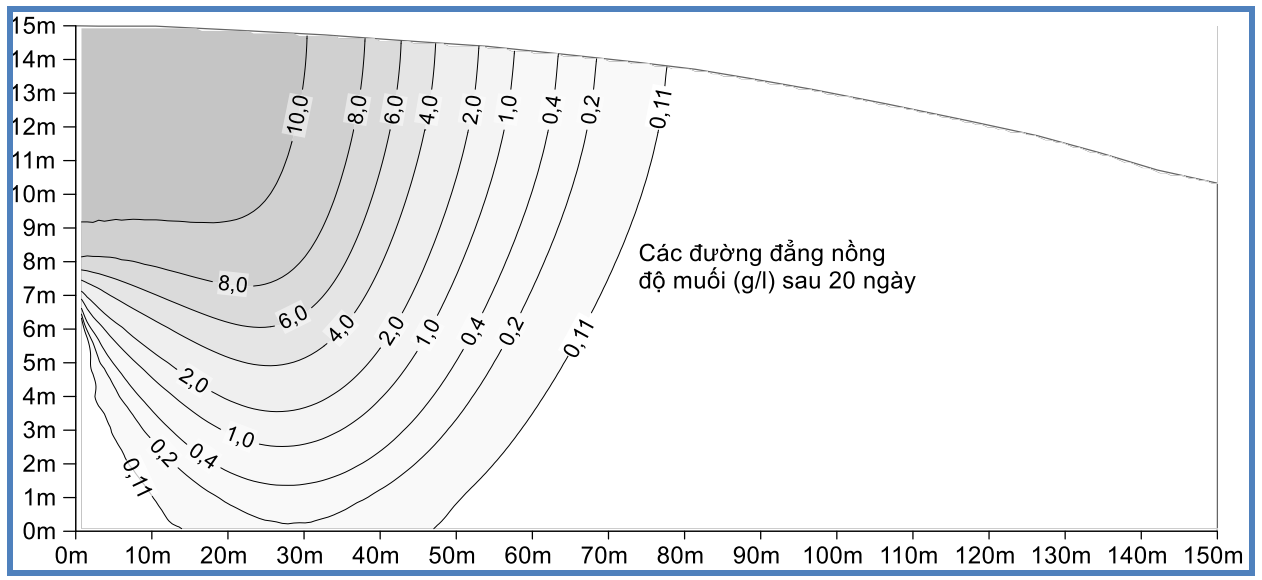

Hình 19. Phân bố nồng độ muối theo không gian và thời gian: sau 20 ngày 
N.V. Hoàng và nnk/Tạp chí Các Khoa học về Trái Đất, Tập 38 (2016)

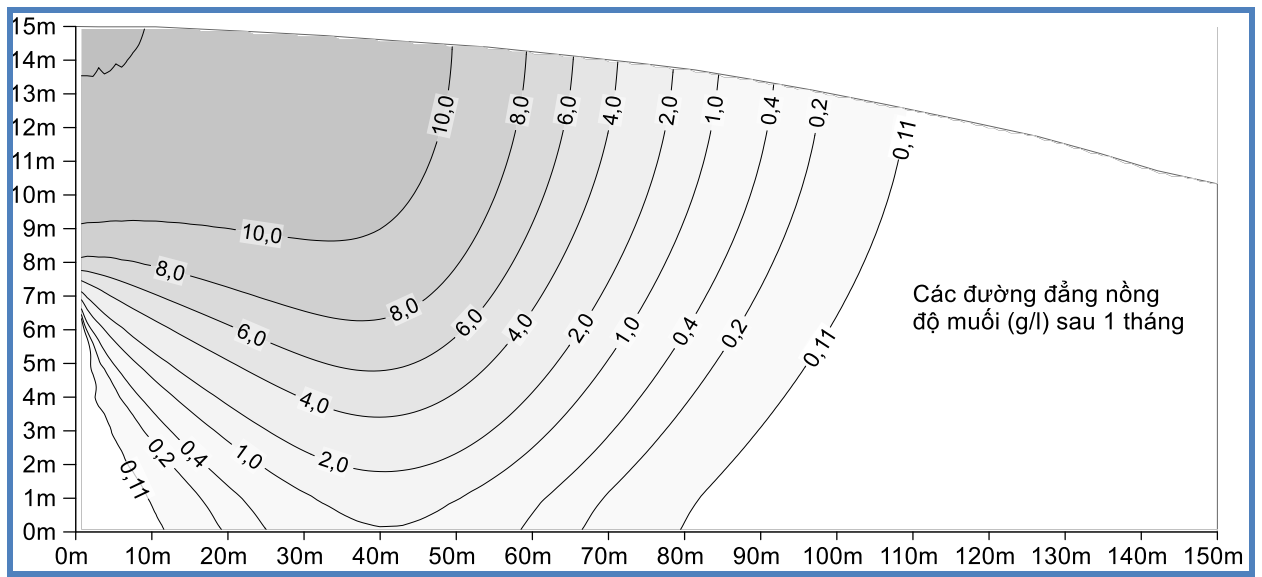

Hình 20. Phân bố nồng độ muối theo không gian và thời gian: sau 1 tháng

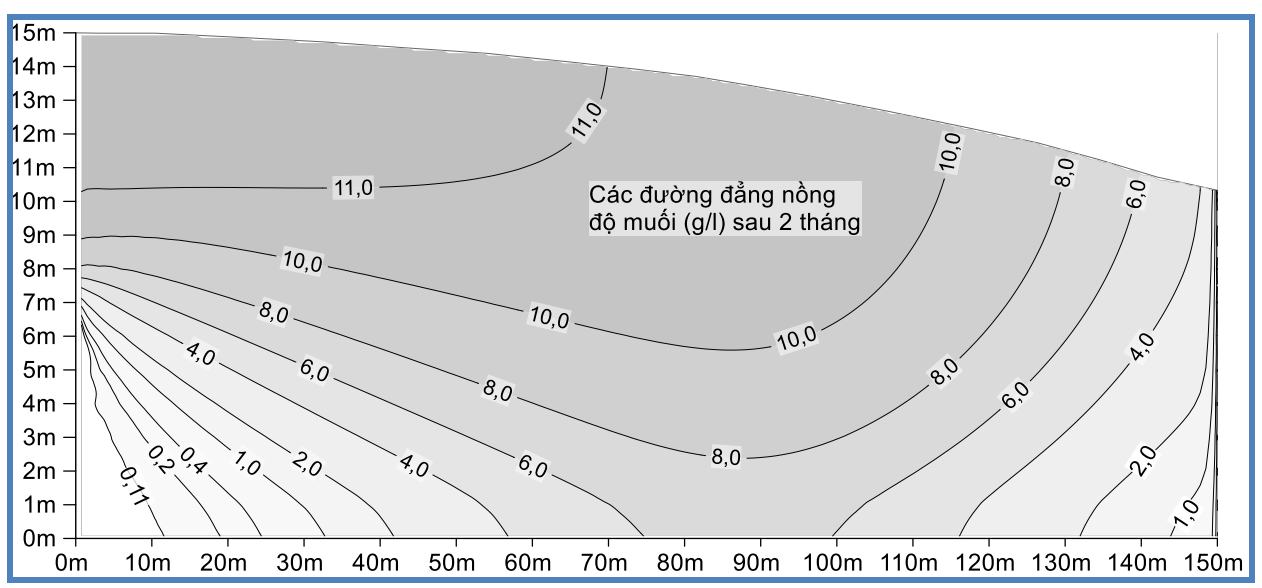

Hình 21. Phân bố nồng độ muối theo không gian và thời gian: sau 2 tháng

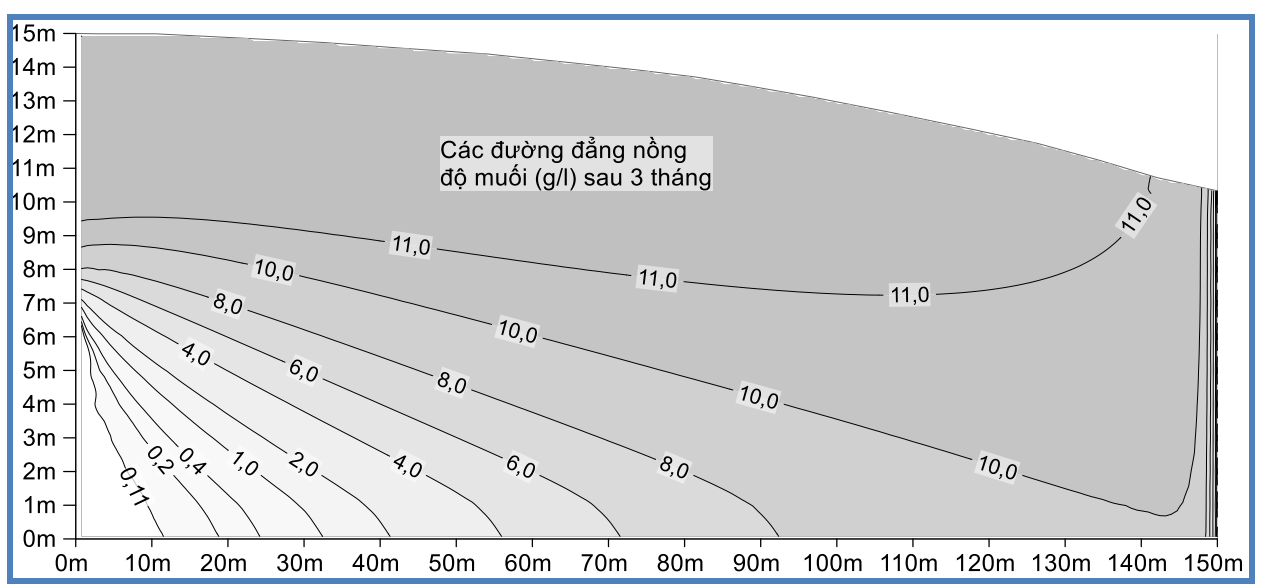

Hình 22. Phân bố nồng độ muối theo không gian và thời gian: sau 3 tháng 
Tạp chí Các Khoa học về Trái Đất, 38 (1), 66-78

\section{Kết luận}

Qua các kết quả mô hình mô phỏng lan truyền mặn trong tầng chứa nước trong không gian hai chiều theo mặt cắt đối với các điều kiện biên và giá trị biên khác nhau, có thể đưa ra một số kết luận sau:

- Chỉ một số trường hợp đặc biệt lan truyền mặn trong nước dưới đất mới có thể được đơn giản hóa thành dạng một chiều hoặc hai chiều đồng nhất trên toàn bộ chiều dày tầng chứa nước, chẳng hạn tầng chứa nước có áp và biên của mặn cắt vào toàn bộ chiều dày tầng chứa nước. Hầu hết các bài toán thực tế lan truyền mặn là 3 hoặc 2 chiều theo trường vận tốc cũng như điều kiện biên có giá trị biên thay đổi theo không gian diện và chiều sâu tầng chứa nước;

- Sự thay đổi trường vận tốc theo phương ngang và phương thẳng đứng trong tầng chứa nước không có áp đã dẫn đến sự thay đổi hệ số phân tán thủy động lực học và cho kết quả lan truyền mặn trong tầng rất phức tạp theo chiều ngang và chiều thẳng đứng;

- Đối với điều kiện biên lan truyền mặn kiểu Dirichlet, trường hợp giá trị nồng độ trên biên là hằng số và trường hợp giá trị nồng độ trên biên thay đổi theo thời gian, nhưng có giá trị trung bình theo thời gian bằng giá trị nồng độ không đổi thì kết quả quá trình lan truyền mặn trong hai trường hợp này là rất tương đồng nhau, chỉ khác nhau không đáng kể ở khu vực sát biên và hạ lưu miền mô hình;

- Đối với kiểu điều kiện biên Cauchy, thuật toán trong mô hình sẽ rất khác nếu lưu lượng dòng chảy qua biên vào tầng chứa nước khác lưu lượng dòng chảy trong tầng chứa nước sát biên; việc xác định sai thực tế này sẽ dẫn đến kết quả mồ hình hoàn toàn sai khác với thực tế;

Qua đây một số kiến nghị sau đây nhằm chính xác hóa các điều kiện thực tế của bài toán lan truyền mặn:

- Xác định chính xác trường vận tốc theo không gian và thời gian là điều rất cần thiết để xây dựng mô hình lan truyền mặn phản ánh đúng thực tế nhất;
- Xác định chính xác điều kiện vật lý của biên miền mô hình lan truyền mặn sẽ góp phần làm sáng tỏ kiểu điều kiện biên (Dirichlet, Neumann hay Cauchy) và giá trị biên;

- Hệ số độ phân tán của môi trường tầng chứa nước là thông số quyết định hệ số phân tán thủy động lực học nước dưới đất nên việc xác định nó là rất cần thiết đối với mô hình mô phỏng lan truyền mặn.

- Có thể tiến hành mô hình xác định sự tương tự, nội suy kết quả trường của hợp biên Cauchy từ kết quả của trường hợp biên Neumann để chuyển từ bài toán rất phức tạp sang bài toán đơn giản hơn nhiều.

\section{Ghi nhận}

Bài báo được hoàn thành trong khuôn khổ Đề tài nghiên cứu cơ bản định hướng ứng dụng mang mã số ĐT.NCCB-ĐHUD.2012-G/04 được tài trợ bởi Qũy phát triển khoa học và công nghệ quốc gia (NAFOSTED), Bộ Khoa học và Công nghệ.

\section{Tài liệu dẫn}

Huyakorn, P.S., Pinder, G.F., 1987: Computational methods in subsurface flow. Academic Press, Inc. Harcourt Brace Jovanivich, Publishers.

Bear, J., Verruijt, A., 1987: Modeling groundwater flow and pollution, D. Reidel Publishing Company, Dordrecht, Holand.

Zienkiewicz, O.C., Morgan, K., 1983: Finite elements and approximation. John Wiley \& Sons.

Phạm Lan Hoa, 2015: Báo cáo chuyên đề thuộc ĐT.NCCBĐHUD.2012-G/04: Xây dựng mô hình phần tử hữu hạn mô phỏng lan truyền các chất ô nhiễm và nhiễm mặn nước dưới đất trình diễn: $1 \mathrm{D}$.

Lê Thanh Tùng, 2015: Báo cáo chuyên đề thuộc ĐT.NCCBĐHƯD.2012-G/04: Xây dựng mô hình phần tử hữu hạn mô phỏng lan truyền các chất ô nhiễm và nhiễm mặn nước dưới đất trình diễn: $2 \mathrm{D}$ theo diện.

Nguyễn Văn Hoàng, 2015. Báo cáo chuyên đề thuộc ĐT.NCCBĐHUDD.2012-G/04: Xây dựng mô hình phần tử hữu hạn mô phỏng lan truyền các chất ô nhiễm và nhiễm mặn nước dưới đất trình diễn: 2D theo mặt cắt. 